\title{
Sediment load variability in response to climate and land use changes in a Carpathian catchment (Raba River, Poland)
}

\author{
Ewa Szalińska ${ }^{1}$ • Paulina Orlińska-Woźniak ${ }^{2}$ • Paweł Wilk ${ }^{2}$
}

Received: 2 June 2019 / Accepted: 5 March 2020 / Published online: 13 March 2020

(C) The Author(s) 2020

\begin{abstract}
Purpose This study analyzes the variability of sediment loads under variant climate change and land use scenarios in a Carpathian catchment with a dam reservoir. The areas with the highest share of sediment loads are tracked to establish possible indications for future catchment management plans.

Materials and methods Analyses were performed for the Raba River catchment (Poland, Carpathian Mountains) with use of the Macromodel DNS/SWAT. The RCP 4.5 climate forecast predictions (2021-2050 and 2071-2100), downscaled for the area of Poland, and land use predictions from the DYNA-Clue model for the Carpathian area, were taken into consideration. A total of seven scenarios were created, accounting for precipitation (P1 and P2), temperature (T1 and T2), land use (LU) changes, and combined effects (COMB1 and COMB2).

Results and discussion The average load delivered to the dam reservoir was estimated as $2.43 \mathrm{Gg} \mathrm{y}^{-1}$, and its seasonal/yearly variability was followed by local meteorological phenomena. Among the tested factors, precipitation change, in terms of total amount and intensity, exerted the most impact on sediment loads causing their increase. Temperature and land use changes resulted in a slight decrease. Combined scenarios implied that changes of the catchment area use, such as increase of forest cover, can noticeably reduce sediment loads delivered into a dam reservoir.

Conclusions The performed simulations revealed the importance of incorporating variant scenarios for catchment management plans, development of land use mitigation measures (erosion), and operational procedures for the dam reservoir. Particular attention should be paid to warmer winters with heavy rainfalls and temperatures above zero, which together with a lack of plant vegetation result in elevated annual sediment loads reaching the dam reservoir. Further changes must be mitigated by anti-erosion investments.
\end{abstract}

Keywords Carpathian catchment $\cdot$ Climate change $\cdot$ Land use change $\cdot$ Sediment loads $\cdot$ Dam reservoir

\section{Introduction}

Climate change impact at the catchment scale has been studied intensely over the last 20 years. Multiple

Responsible editor: Susanne Heise

Electronic supplementary material The online version of this article (https://doi.org/10.1007/s11368-020-02600-8) contains supplementary material, which is available to authorized users.

Ewa Szalińska eszalinska@agh.edu.pl

1 Faculty of Geology, Geophysics and Environmental Protection, AGH University of Science and Technology, A. Mickiewicza Ave. 30, 30-059 Cracow, Poland

2 Institute of Meteorology and Water Management, National Research Institute, 61 Podleśna St, 01-673 Warsaw, Poland publications have reported alterations in flow characteristic, flood event frequency, and snow cover extent (Bussi et al. 2016; Hattermann et al. 2017). Moreover, these alterations are further amplified by shifts in the land use induced by temperature and precipitation changes (Wang et al. 2016; Bussi et al. 2017) or resulting from socioeconomic reasons (Grecequet et al. 2017). Since these shifts of water and runoff cycles can severely disturb natural processes like weathering and erosion, changes in sediment fluxes can also be expected (Simonneaux et al. 2015; Yang et al. 2015). Assessment of sediment quantities delivered from a catchment is particularly important for regions that are highly vulnerable to erosion, e.g., mountainous areas with high slopes, and/or intensive and frequent rainfalls. Also, sediment continuity in a majority of these catchments has been obstructed by anthropogenic factors, e.g., alterations to channel morphology, or construction of dams and reservoirs (Apitz 2012; 
Ahilan et al. 2018). Especially, in the latter case, estimations of the sediment accumulation rate and remaining reservoir capacity are of a crucial significance (Alighalehbabakhani et al. 2017). Current studies related to sediment quantity estimations under climate change scenarios generally predict an increase of sediment loads under an upward trend of average precipitation due to intensification of soil erosion ( $\mathrm{Lu}$ et al. 2013; Darby et al. 2015; Zhou et al. 2017; Giardino et al. 2018; Barrera Crespo et al. 2019). However, the response in individual catchments can vary due to possible changes in vegetation cover, as a result of water balance changes, reducing erosion in the area. The response of catchment models to temperature changes is even more complex, naturally displaying either an increase or a decrease in sediment loads (Bussi et al. 2016). Since temperature shifts can affect catchment water balance through various local phenomena, e.g., early snowmelt, droughts/rainfall occurrence, and distribution of vegetation cover, their impact on sediment loads seems to be strongly related to catchment geographical settings (Jentsch and Beierkuhnlein 2008; Ricci et al. 2018; Shrestha and Wang 2018). Therefore, to produce reliable predictions, modeling efforts should incorporate results of downscaled climate predictions, account for regional trends in land use change, and analyze them simultaneously (Bussi et al. 2016).

The main goal of the study was to analyze the variability of sediment loads under variant climate change and land use scenarios in a Carpathian catchment with a dam reservoir. The Raba River (southern Poland) has been selected as the study venue, since its catchment represents the most typical conditions for this region. The upper part of this river flows through a mountainous area with a considerable number of agricultural fields. Also, the river features a drinking water dam reservoir, accumulating sediments delivered from the upper part of the catchment. The sediment load variability was tested with use of the Macromodel DNS/SWAT (Discharge-Nutrient-Sea/Soil Water Assessment Tool) under the RCP4.5 climate change predictions, downscaled for the Polish area (Mezghani et al. 2017). To account for local land use changes, the results from the DYNA-Clue (Dynamic Conversion of Land Use and its Effects) model for the area of interest were taken into consideration (Price et al. 2017). Besides tracking the effects of individual precipitation, temperature, and land use changes, the goal of the study was to observe the impact of the combined changes on the sediment loads. Delimitation of the sub-catchments with the highest portion of sediment loads delivered to the reservoir was tracked to establish possible indications for future catchment management plans.

\section{Materials and methods}

\subsection{Research area}

The Raba River (131.9 km) flows from the Carpathian belt of the Gorce Mountains (source-780 m a.s.1.) to the Vistula River (outlet-180 m a.s.1.), and constitutes its right-side tributary (Fig. 1). This river features a dam reservoir (Dobczyce) at $60.1 \mathrm{~km}$, which is the main source for drinking water of approximately half a million people (Mazurkiewicz-Boron 2016; Operacz 2017). The Raba River catchment $\left(1537.1 \mathrm{~km}^{2}\right)$ has a pronounced dual character, a mountainous part located upstream from the reservoir, and a sub-montane following the downstream reach of the river. These parts are very different in terms of terrain slope, soil type, and land use. The upper part of the basin is characterized by high slopes, forested areas, and loamy soils, while the lower part is covered mainly by loess and the land use is dominated by agriculture. The mountainous nature of the upper part of the Raba River catchment manifests with a fast reaction to precipitation, due to its high slope gradients and relatively low soil permeability. The river features very large amplitudes of water levels and flows, with maximum values recorded in the snow melt period, and early summer long-lasting rainfall events. The following sediment load variability was analyzed for the Myślenice calculation profile (Fig. 1) which encompasses the upper part of the Raba River catchment, and constitutes the last water gauge/monitoring point upstream from the reservoir. Selection of this calculation profile allowed us for the first time to simulate the effects of climate change in the Polish Carpathians on the sediment load delivered to the dam reservoir.

\subsection{Macromodel DNS/SWAT}

The spatio-temporal variability of the sediment loads for the Raba River catchment was analyzed with use of the Macromodel DNS/SWAT which was developed at the Institute of Meteorology and Water Management-National Research Institute (Instytut Metorologii i Gospodarki Wodnej-Państwowy Instytut Badawczy-IMGW-PIB), and described previously (Ostojski 2012; Wilk et al. 2017, 2018a, b; Szalinska and Wilk 2018; Szalińska et al. 2018). Briefly, the developed Macromodel provides a platform where the SWAT module (Arnold et al. 2012; Abbaspour et al. 2015) is integrated with other models (e.g., hydrological and meteorological), and in-situ and/or remote catchment data. The SWAT module itself has been recognized by the Nexus Tool Platforms (Mannschatz et al. 2016) as the best available hydrological model, based on its easy accessibility, wide application possibilities, and numerous publications which can support current and new users. In the current research, the 


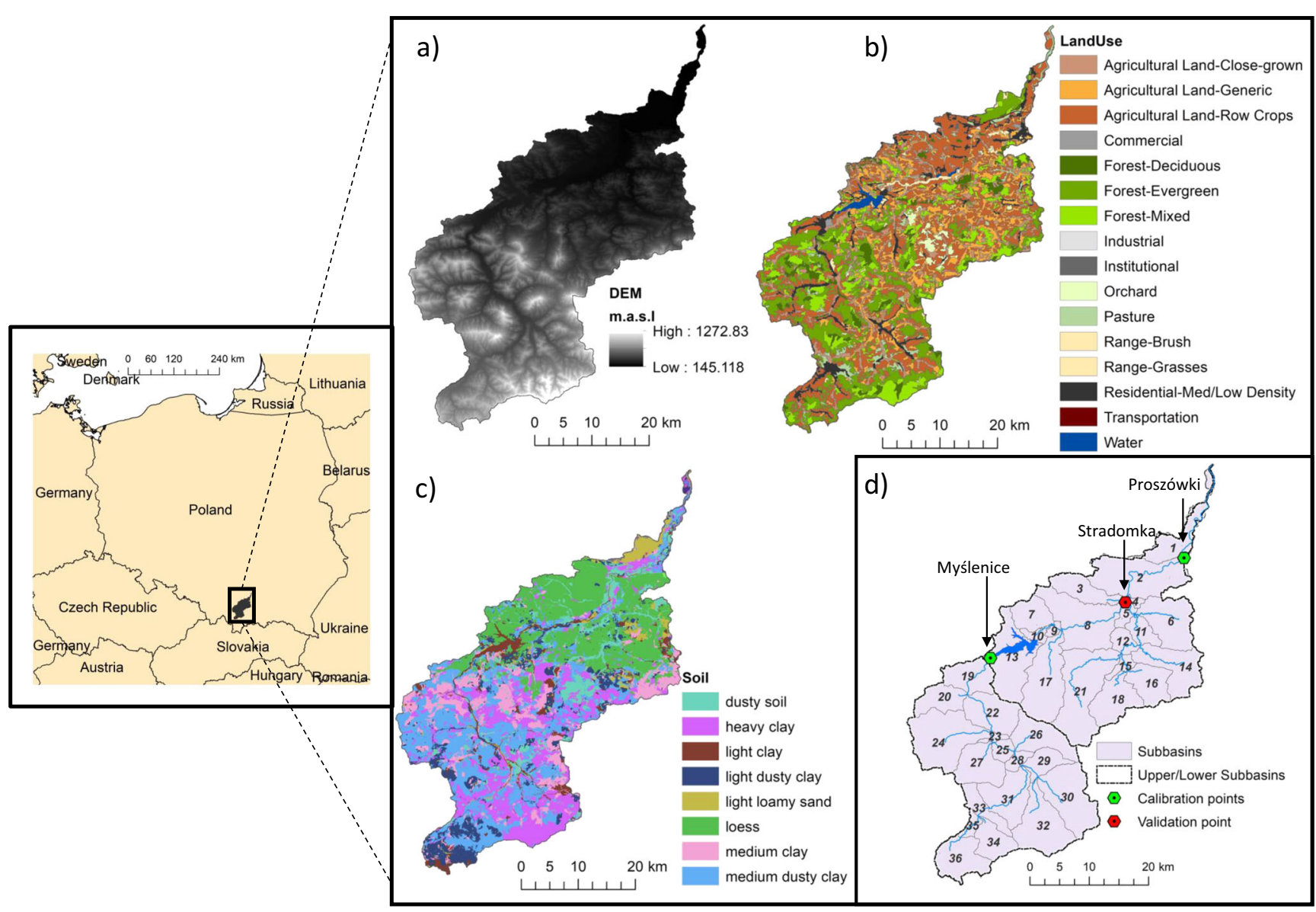

Fig. 1 Location of the Raba River catchment with maps of a slope, $\mathbf{b}$ land use, $\mathbf{c}$ soil type, and $\mathbf{d}$ calculation profiles of Myślenice and Proszówki

SWAT model version 2012 has been used. The Macromodel DNS/SWAT is characterized by a high flexibility and facilitates analyses and illustration of relationships between input and output variables.

Moreover, this Macromodel allows creation of variant scenarios, and investigation of effects caused by the change of one or several parameters in a time perspective. To create the Raba River catchment model the following data have been used:

- map of Poland hydrographical divisions, scale of 1:10,000 (source: IMGW-PIB, resolution: $5 \mathrm{~m}$ );

- digital elevation model (DEM), scale of 1:20,000 (source: IMGW-PIB, resolution: $10 \mathrm{~m}$ );

- soil map-detailed data on soil types (Table S1, Electronic Supplementary Material-ESM), scale of 1:5000 (source: Institute of Soil Science and Plant Cultivation, resolution $2.5 \mathrm{~m}$ );

- land use map - based on Corine Land Cover (CLC 2012), and agrotechnical data from the Local Data Bank (source: Copernicus Programme, resolution $20 \mathrm{~m}$ ) and;

- meteorological data (1992-2016, e.g., precipitation and temperature) for 75 stations located directly in the catchment, and within $20 \mathrm{~km}$ from its borders (source: IMGW-PIB).
To facilitate detailed spatial analysis of the sediment load sources, the studied catchment has been divided into 50 sub-catchments, based on the surface water bodies (SWB) division. To accommodate some modeling needs (large urban areas, dam reservoir, and in-situ tests) selected sub-catchments were modified according to the location of computational profiles.

The SWAT model offers four methods to simulate sediment transport (i.e., Bagnold, Kodoatie, Molinas, and Wu and Yang sand and gravel method). In the current study, the Kodoatie method was chosen because it allows us to analyze sediment load by individual fractions. Moreover, it is considered to be particularly effective for suspended and small sediment particles. This method has been described as an optimized sediment transport equation, using non-linear optimization and field data for different river sediment particle sizes (Kodoatie 2000; Ayaseh et al. 2019).

$\operatorname{conc}_{s e d, c h, m x}=\left(\frac{a^{*} v_{c h}^{b} * y^{c} * S^{d}}{Q_{i n}}\right) *\left(\frac{W+W_{b t m}}{2}\right)$

Where: conc $_{\text {sed, }, c h, m x}$ is the maximum sediment concentration $\left(\mathrm{t} \mathrm{m}^{-3}\right) ; v_{c h}$ is mean flow velocity $\left(\mathrm{m} \mathrm{s}^{-1}\right) ; y$ is mean flow depth (m); $S$ is energy slope $\left(\mathrm{m} \mathrm{m}^{-1}\right) ; Q_{i n}$ is water entering the 
reach $\left(\mathrm{m}^{3}\right) ; a, b, c$, and $d$ are regression coefficients for different bed materials; $W$ is channel width at the water level (m); and $W_{b t m}$ is bottom width of the channel (m).

\subsection{Sensitivity analysis, calibration, and validation of the model}

The SWAT-CUP (calibration and uncertainty program, Fukunaga et al. 2015) and its SUFI-2 algorithm were employed to perform sensitivity, calibration, and uncertainty analyses of the model runs (Kumar et al. 2017). Sensitivity of parameters was determined with use of a multiple regression model, which regresses the Latin hypercube-generated parameters against an objective function based on defined values for calibrated variables (Abbaspour et al. 2015). Sensitivity analysis results for parameters of flow and sediment are listed in Table S2 (On-line Supplementary Material).

Model calibration and validation were performed with use of the flow data obtained from the IMGW-PIB, and total suspended sediment concentrations from the state monitoring system (Polish Inspectorate of Environmental Protection). Due to the fact that the state monitoring frequency is relatively low (12 times per year), the LOAD ESTimator program (LOADEST) (https://water.usgs.gov/software/loadest/) was used to assist in the development of the regression model for reliable estimation of constituent load (calibration). Explanatory variables within the regression model included functions of streamflow, decimal time, and additional userspecified data variables. The formulated regression model then was used to estimate loads over a user-specified time interval (estimation). Mean load estimates, standard errors, and $95 \%$ confidence intervals were developed on a monthly and seasonal basis (Krishnan et al. 2018; Lee et al. 2018). Due to the dual character of the Raba River catchment, the calibration process was performed for the two parts of the catchment separately. For the upper part, the catchment calibration was performed in the calculation profile of Myślenice, while the profile of Proszówki was selected for the lower part (Fig. 1d). The results obtained for both profiles were used to calibrate and verify the model.

Validation of the model was performed for the Stradomka River, which is a right-bank tributary of the Raba River and is also subjected to suspended sediment state monitoring measurements. To assess fitness of the model to the monitoring results, four statistical measures, coefficient of determination $(R 2)$, the Nash-Sutcliffe model efficiency coefficient (NSE), percentage of bias (PBIAS), and Kling-Gupta efficiency (KGE) have been used (Patil and Stieglitz 2015; Xing et al. 2018; Da Silva et al. 2018; Libera and Sankarasubramanian 2018). The obtained calibration and validation results for individual statistical measures and time periods are presented in Table S3 and Fig. S1 (On-line Supplementary Material).

\subsection{Modeling scenarios}

To discuss climate and land use change impact for the sediment load, several variant scenarios have been created for the study area. Their reference point is the baseline scenario (0), which is a simulation of the Raba River model that passed the calibration procedure. To account for the predicted climate changes (precipitation and temperature) for two future time horizons (2021-2050 and 2071-2100) based on RCP4.5, the results of the dynamical downscaling for the area of Poland were taken into consideration (Mezghani et al. 2017; Climateimpact 2019). Accordingly, two precipitation (P1 and $\mathrm{P} 2$ ) and two temperature (T1 and $\mathrm{T} 2$ ) scenarios have been created (Table 1).

The land use scenario (LU) has been based on the results of the FORECOM project (http://www.gis.geo.uj.edu. $\mathrm{pl} /$ FORECOM/index.html) implemented to improve understanding of past, present, and future forest cover changes in the Swiss Alps and the Polish Carpathians in the context of climate changes. The LU scenario implemented in the current study was based on the DYNA-Clue model for the two Carpathian localities (Szczawnica and Niedźwiedź) for the future time horizon of 2060 (Price et al. 2017). This scenario assumed an increase of forested areas by $16 \%$, and an increase of urban areas by $6 \%$, at the expense of areas used for agriculture. In the SWAT model, land use is one of the pivotal elements for catchment division into the hydrologic response units (HRU), which are the basis of the model's structure and subsequent simulations. The HRUs are defined by lumping similar land use, soil, and slope, and they are not spatially distributed. Therefore, land use changes for the LU scenario were applied using a dedicated function (land use update). This function allowed for dynamic changes during simulation imitating the surface changes for individual types of land use (Marhaento et al. 2017). To assess combined effects of all forecasted changes, final scenarios for the near $(\mathrm{COMB} 1=\mathrm{P} 1+\mathrm{T} 1+\mathrm{LU})$ and far future $(\mathrm{COMB} 2=\mathrm{P} 2+\mathrm{T} 2+\mathrm{LU})$ have been created.

\section{Results}

Results of the Macromodel DNS/SWAT enabled the sediment load analysis in the Myślenice calculation profile located directly upstream from the Dobczyce Reservoir. The average annual sediment load flowing into the reservoir has been estimated at $2.43 \mathrm{Gg} \mathrm{y}^{-1}$ for the baseline scenario (0) (Table 2). Analysis of the temporal variabilities for this load revealed statistically significant differences among season averages $(n=25$, ANOVA, $p<0.05)$, with the lowest average load share detected in autumn (19\%). For the remaining seasons, the average loads constituted $26 \%$ of the total values during 
Table 1 Median changes (RCP4.5) of precipitation $(\%)$ and temperature $\left({ }^{\circ} \mathrm{C}\right)$ for the Myślenice calculation profile for the adopted climate and land use scenarios

\begin{tabular}{|c|c|c|c|c|c|}
\hline & & $\begin{array}{l}\text { P1 } \\
2021-2050\end{array}$ & $\begin{array}{l}\text { P2 } \\
2071-2100\end{array}$ & $\begin{array}{l}\text { T1 } \\
2021-2050\end{array}$ & $\begin{array}{l}\text { T2 } \\
2071-2100\end{array}$ \\
\hline Winter & (Dec-Feb) & 9.5 & 16.74 & 1.1 & 2.29 \\
\hline Spring & (Mar-May) & 8 & 15.89 & 0.84 & 1.83 \\
\hline Summer & (Jun-Aug) & 2.63 & 1.21 & 1.01 & 1.68 \\
\hline Autumn & (Sep-Nov) & 2.11 & 4.25 & 0.95 & 1.88 \\
\hline
\end{tabular}

the spring and summer months, and $29 \%$ in the winter. For all seasons, a statistically significant relationship between sediment load and precipitation has been detected $(p<0.02)$, with $R$ values ranging from 0.66 to 0.79 for spring, summer, and autumn, and equal to 0.48 for winter. The variability of seasonal loads (Fig. 2) reflects local meteorological phenomena, e.g., occurrences of a snow melt in the winter months of 1993, and 2003 (45\% of total load), or occurrence/intensity of precipitation during the summer of 2005 (up to $47 \%$ of the total load). Also, the impact of wet/dry years is clearly visible in the temporal sediment load distribution. For instance, 1996, considered as one of the driest years in the analyzed period, noticeably impacted the sediment load at the calculation profile, especially in the winter. In turn, the flood of 2010 contributed to a rapid increase of the sediment load, compared to 2009. In May 2009, 0.1 Gg of sediment, on average, passed through the calculation profile, while in May 2010, this value rose to approximately $1 \mathrm{Gg}$.

Application of precipitation and temperature scenarios provided an opportunity to assess possible impact of future climate changes on reservoir siltation, which is an issue of key impact since the analyzed catchment is located in an area very prone to erosion. If we assume a hypothetical situation that the future climate will only cause an increase of average annual rainfall level, then such a change will increase the sediment load flowing into the reservoir by over $8 \%$ for the near future scenario $(\mathrm{P} 1)$, and by over $20 \%$ for the far future (P2). Even more pronounced differences in the precipitation impact can be observed when the sediment load has been split seasonally. A similar increase of the winter and spring average values has been detected for the near future scenario (P1, approx. 10\%), while the predicted far future change (P2) distinguished the spring load change with an increase by $35 \%$ ( $0.2 \mathrm{Gg}$ per season). Also, the highest variability of the average loads for this season should be observed, with a 5-95 percentile range of $0.77-1.56 \mathrm{Gg}$. As for the summer and autumn periods, changes of the average sediment loads did not exceed $8 \%$ (P2). If only temperature changes occur separately in the future, we could expect a decrease of the annual average sediment loads by approx. $6 \%$ for the $\mathrm{T} 1$ scenarios, and $3 \%$ for the $\mathrm{T} 2$ scenario. The decreasing pattern for temperature was detected for all seasons, except for the T2 scenario in winter where the sediment load increased by $6 \%$. The largest sediment load reduction in the range of $11-13 \%$ (for $\mathrm{T} 1$ and $\mathrm{T} 2$, respectively) occurred in spring. In the remaining seasons, sediment load reduction remained under $5 \%$. The land use scenario (LU), resulting in a decrease of the area used for agricultural purposes by $22 \%$, reduced the average

Table 2 Yearly $\left(\mathrm{Gg} \mathrm{y}^{-1}\right)$ and seasonal $\left(\mathrm{Gg}_{\text {season }}{ }^{-1}\right)$ average sediment loads for the Myślenice calculation profile under climate and land use change scenarios within the 5-95 percentile range

\begin{tabular}{llllllllll}
\hline Scenario & & 0 & P1 & P2 & T1 & T2 & LU & COMB1 & COMB2 \\
\multirow{2}{*}{ Time horizon } & 1992-2016 & $2021-2050$ & $2071-2100$ & $2021-2050$ & $2071-2100$ & -2060 & $2021-2050$ & $2071-2100$ \\
\hline \multirow{2}{*}{ Year } & Mean & 2.43 & 2.63 & 2.90 & 2.29 & 2.35 & 2.30 & 2.39 \\
& Perc. 5-95 & $1.42-3.96$ & $1.60-3.91$ & $1.80-4.64$ & $1.45-3.80$ & $1.37-4.10$ & $1.34-3.70$ & $1.56-3.90$ & $1.59-4.37$ \\
\multirow{2}{*}{ Winter } & Mean & 0.71 & 0.78 & 0.88 & 0.67 & 0.75 & 0.65 & 0.66 \\
& Perc. 5-95 & $0.31-0.85$ & $0.35-0.89$ & $0.40-1.01$ & $0.32-1.08$ & $0.37-1.14$ & $0.30-0.79$ & $0.36-0.93$ & $0.44-1.43$ \\
\multirow{2}{*}{ Spring } & Mean & 0.63 & 0.70 & 0.85 & 0.56 & 0.55 & 0.58 & 0.63 \\
& Perc. 5-95 & $0.53-1.21$ & $0.66-1.20$ & $0.77-1.56$ & $0.47-1.10$ & $0.50-1.18$ & $0.51-1.15$ & $0.55-1.20$ & 0.73 \\
\multirow{2}{*}{ Summer } & Mean & 0.63 & 0.67 & 0.68 & 0.62 & 0.62 & 0.62 & 0.65 \\
& Perc. 5-95 & $0.24-1.32$ & $0.27-1.27$ & $0.28-1.36$ & $0.21-1.34$ & $0.19-1.57$ & $0.23-1.27$ & $0.23-1.42$ & $0.22-1.45$ \\
\multirow{2}{*}{ Autumn } & Mean & 0.45 & 0.47 & 0.48 & 0.43 & 0.43 & 0.44 & 0.45 \\
& Perc. 5-95 & $0.22-0.90$ & $0.23-0.95$ & $0.24-0.94$ & $0.21-0.87$ & $0.21-0.87$ & $0.22-0.87$ & $0.22-0.88$ & $0.23-0.93$ \\
\hline
\end{tabular}



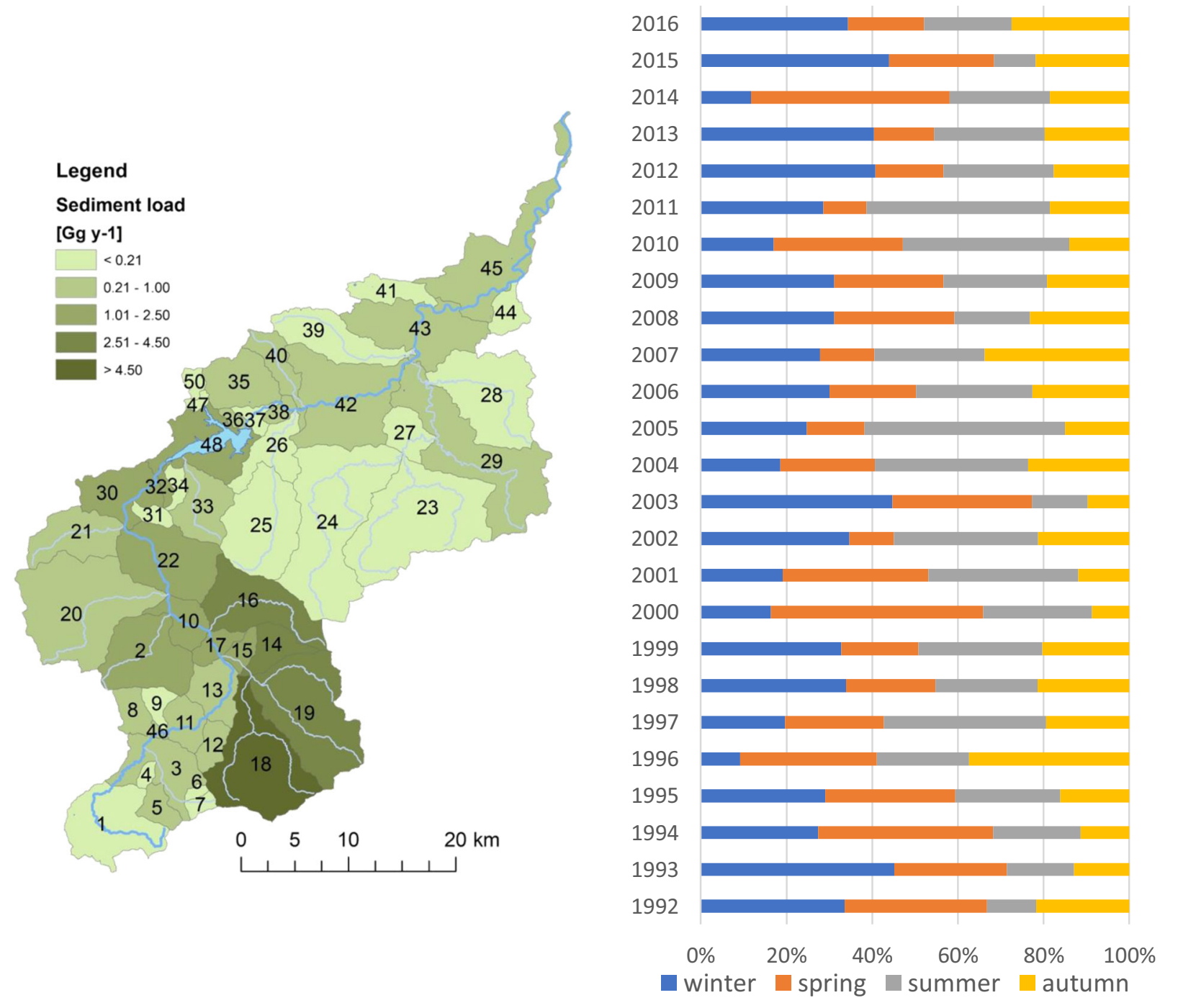

Fig. 2 Sub-catchment sediment loads and seasonal sediment pattern for the Raba River baseline scenario for the Myślenice calculation profile

yearly sediment load by approximately $5 \%$. Seasonal differences for LU were uniform for winter and spring (approx. 8\%) and for summer and autumn (approx. 2\%).

However, since the predicted changes most probably will occur simultaneously in the catchment, the cumulative effect of the scenarios should be taken into consideration. Therefore, by combining corresponding scenarios for the adopted time horizons $(\mathrm{P} 1+\mathrm{T} 1+\mathrm{LU}$, and $\mathrm{P} 2+$ $\mathrm{T} 2+\mathrm{LU})$, two combined scenarios have been created (COMB1 and COM2). The near future predictions (COMB1) resulted only in a slight decrease of the yearly average load in the calculation profile by $2 \%$. A similar trend was followed by the seasonal average loads, with the exception for the summer period, when an approx. $3 \%$ increase was observed. For the far future scenario (COMB2), a sediment load increase for the yearly and seasonal average values was detected, from $2 \%$ for the autumn period, up to $23 \%$ in the winter months.
Despite the fact that the study focused on the sediment load delivered into the dam reservoir, the other computational profiles located in the catchment have been also investigated. Since most of the Carpathian catchments are subjected to intense erosional processes, planning of the mitigation action must be effective and very precise. The use of the Macromodel DNS/SWAT enabled spatial analysis of the sediment load sources distributed in all Raba River sub-catchments (Fig. 2). The baseline scenario for the Raba River revealed sub-catchments with the highest sediment load, exceeding $2.5 \mathrm{Gg} \mathrm{y}^{-1}$. All of them (Nos. 18, 19,14 , and 16) are located in the upper part of the catchment and are characterized by large averages slopes $(28.5 \%, 22.6 \%, 18.7 \%$, and $20.9 \%$, respectively), and intensive precipitation (approx. $1400 \mathrm{~mm} \mathrm{y}^{-1}$ ). Particularly interesting is sub-catchment No. 18 , releasing over $4.5 \mathrm{Gg} \mathrm{y}^{-1}$ of sediment, which has slopes of the highest elevation peak in this region (Turbacz, $1310 \mathrm{~m}$ a.s.l.). 


\section{Discussion}

Estimation of sediment loads released from catchments has a long tradition and is crucial for various ecological and technical perspectives, especially in catchments heavily affected by anthropogenic activity (Fox et al. 2016; Walling 2017). Currently, such estimations are generally performed with use of modeling tools, enabling them to provide fairly accurate predictions, and to delineate areas contributing the most to the total sediment load (Liu et al. 2015; Nguyen et al. 2019). The sediment load variability has been investigated for the Myślenice profile localized in the direct vicinity of the river outlet to the dam reservoir (Dobczyce). Since this reservoir is supplied mostly by the Raba River (approx. 90\% of total inflow), this profile can be considered as representative of the sediment loads delivered from the upper part of the catchment. According to the baseline scenario (0), based on a quarter century observation (1992-2016), $2.43 \mathrm{Gg} \mathrm{y}^{-1}$ of sediment on average passes through this calculation profile, and this value remains in concordance to the results of other studies (Drzewiecki and Mularz 2008). The range of the sediment loads in this profile is very broad $\left(1.42-3.96 \mathrm{Gg} \mathrm{y}^{-1}\right)$ and generally follows the occurrence of dry (1992-1996) and wet (2005, 2010, and 2014) years (Fig. 3). Moreover, an impact of precipitation regimes can be tracked from the
Macromodel results. The two highest sediment loads were recorded in 2005 and 2010 (3.9 and $3.1 \mathrm{Gg} \mathrm{y}^{-1}$, respectively), which were the years with exceptional rainfall. The total yearly sum of precipitation reached over $1275 \mathrm{~mm}$ in 2005, while in 2010, which was the year that had the biggest floods in Poland, surpassed $1800 \mathrm{~mm}$. The lowest sediment load was detected in $1993(1.31 \mathrm{Gg})$, when the total rainfall remained under $1000 \mathrm{~mm}$. In August 2014, the occurrence of short-term but very heavy rainfalls (with average hourly intensity above $40 \mathrm{~mm} \mathrm{~h}^{-1}$ ) in the analyzed area (Bryndal et al. 2017) was responsible for a significant sediment load increase, reaching up to $0.8 \mathrm{Gg} \mathrm{m}^{-1}$ (Fig. 3).

Analysis of the temporal patterns revealed winter as the most important sediment delivery season. Although this period (December-February) is not abundant with precipitation, the occurrence of atypical high rainfall events have been observed in this area during the winter months, during so-called anomalously wet seasons (AWS) (Cebulska and Twardosz 2014). Also, a decrease of snowfall and an early snow melt have to be considered very important factors increasing total loads during winter seasons in this region (Stryker et al. 2018). Available meteorological data (source: IMGW-PIB) clearly show a gradual shortening of periods with air temperatures below $0{ }^{\circ} \mathrm{C}$ and snow cover. These phenomena combined with lack of vegetation cover could largely enhanced soil particle

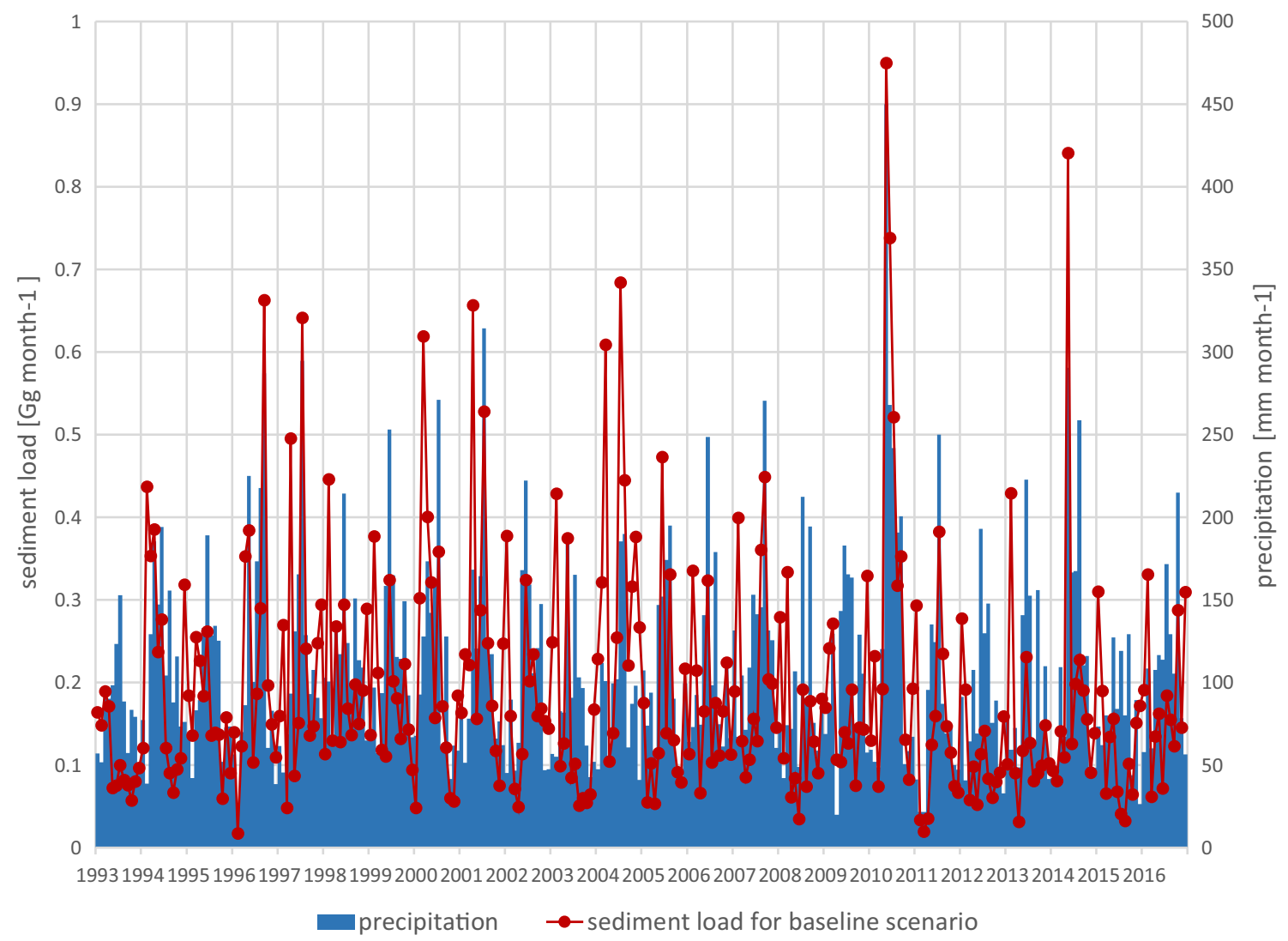

Fig. 3 Temporal distribution (1992-2016) of sediment loads $\left(\mathrm{Gg}\right.$ month $\left.{ }^{-1}\right)$ with respect to precipitation (mm month $\left.{ }^{-1}\right)$ for the Myślenice calculation profile 
transport from the catchment to the receiving water body. The lowest sediment loads were generally detected during autumn (September-November), which is typically considered as dry and as a low flow season for the Carpathian watercourses (Jokiel and Tomalski 2017).

The relationship between sediment load and precipitation is even more visible when climate changes are being discussed. This is particularly important for this catchment area since the precipitation pattern in the Carpathian region already differs from the values adopted for the rest of the country, exceeding the Polish average value $(600 \mathrm{~mm})$ by $60-150 \%$. The increased values of precipitation imposed on the baseline Raba River model (0) under the adopted climate scenarios (P1 and $\mathrm{P} 2$ ) resulted in a further increment of the sediment loads by almost $0.20 \mathrm{Gg} \mathrm{y}^{-1}$ in the near and $0.48 \mathrm{Gg} \mathrm{y}^{-1}$ in the far future simulations. Since the forecasted precipitation changes clearly amplify the seasonal variability (Table 1), even bigger sediment loads could be introduced to the reservoir during the winter and spring periods.

Nonetheless, the opposite decreasing trend of sediment loads should be considered when temperature and land use changes are taken into consideration. The local temperature growth predictions, estimated on average at $1{ }^{\circ} \mathrm{C}$ for the near and at $2{ }^{\circ} \mathrm{C}$ for the far future simulations for this area, are considerably lower than the values adopted in similar studies (Tasser et al. 2017; Zhou et al. 2017). The modeling results revealed a considerable drop of sediment load between 0 and $\mathrm{T} 1$ scenarios (approx. $0.14 \mathrm{Gg} \mathrm{y}^{-1}$ on average), however, the increased temperature growth by $1{ }^{\circ} \mathrm{C}(\mathrm{T} 2)$ produced a relatively low change of $0.08 \mathrm{Gg} \mathrm{y}^{-1}$ (Table 2). To elucidate this issue, several additional variant scenarios were run to simulate a gradual change of temperature (Fig. 4).

The obtained results suggest that the initial temperature change by $0.25{ }^{\circ} \mathrm{C}$ in the Macromodel DNS/SWAT already resulted in a sudden decrease of yearly average sediment load (approx. $0.1 \mathrm{Gg} \mathrm{y}^{-1}$ ). This initial drop of sediment load is most likely caused by the SWAT model specificity and its sensitivity to even small changes of the variant parameters. Although a plethora of studies have reported a temperature impact on sediment loads (Bussi et al. 2016; Ahilan et al. 2018), such results have never been reported before, which suggests that this issue must be further investigated. The following values, up to the temperature rise of $2{ }^{\circ} \mathrm{C}$ (T2), showed only slight variability, in the range of 3-6\% of the T0.25 sediment load value. This load stabilization phenomena suggests that the forecasted temperature changes below $2{ }^{\circ} \mathrm{C}$ have an insignificant influence on the sediment load in the analyzed profile, while the subsequent increase of temperature (T2.5-T4) will cause a tangible decrease of sediment loads in the catchment. Temperature rise is supposed to change evapotranspiration and extend the vegetation season, and thus retain plant cover thereby decreasing overall rainfall erosion for longer periods (Routschek et al. 2014). However, this may also cause water depletion in the catchment ( $\mathrm{Lu}$ et al. 2013) and induce faster snowmelt, which can hypothetically result in higher erosion (Zhou et al. 2017). Therefore, it is strongly recommended that modeling studies should focus on different geographical settings of the studied catchments.

The Macromodel DNS/SWAT also revealed subcatchments particularly prone to sediment release (Fig. 2). Generally, the Raba River catchment is strongly exposed to erosional processes, controlled mainly by land slope, soil characteristics, and land use. The upper part of the studied area features very high slopes (average of $23 \%$ ), and despite predominant forest land cover (50\% of the upper Raba River catchment), is highly prone to sediment release. Moreover, the sub-catchments with elevated sediment load proportions (Nos. 18, 19, 14, and 16; Fig. 2) are abundant within agricultural

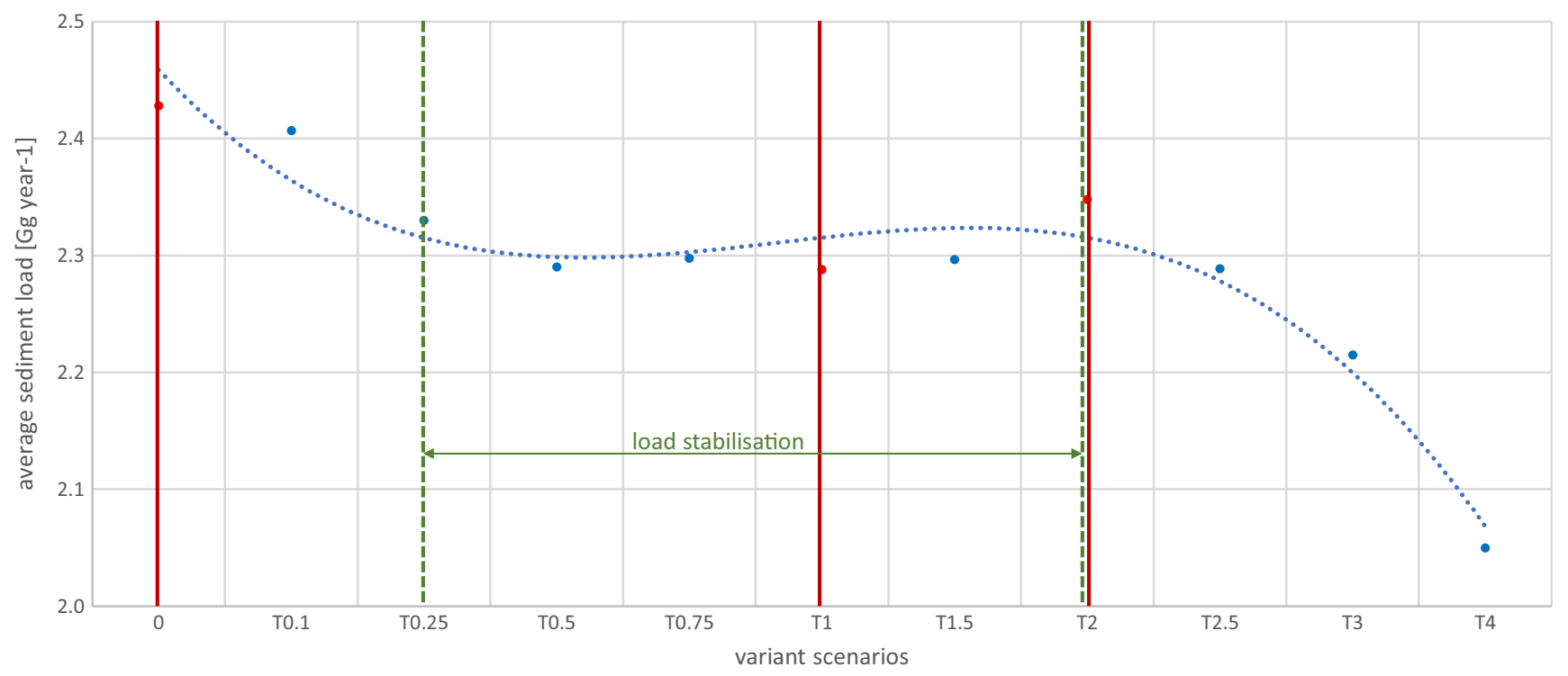

Fig. 4 Variability of sediment loads $\left(\mathrm{Gg} \mathrm{y}^{-1}\right)$ for the Myślenice calculation profile for temperature change scenarios (T0.1-T4) 
lands (40\%), with fields located on the lower slopes. The lower part of the catchment (downstream from the reservoir) is mainly used for agricultural purposes (63\% of the area of the lower Raba River catchment). Therefore, its soil erodibility factor is generally higher than in the upper part (dominant USLE-k factor for the lower Raba River catchment -0.2 , for the upper part- 0.14 ), however, the significantly lower slope angles (average of $12 \%$ ) result in a lower intensity of erosion.

As for the predicted land use and land cover changes, refrainment from agricultural activities in the mountainous regions and gradual reforestation of the abandoned areas has already been observed in some regions (Price et al. 2017; Tasser et al. 2017). Moreover, due to socioeconomic changes, areas used for agriculture are gradually being transformed and used for non-agricultural purposes, including residential, construction, or service facilities (Verburg et al. 2008; Bucała-Hrabia 2017a, b; Szwagrzyk et al. 2018). Such changes may have contradictory impacts on the formation of runoff, and therefore for the sediment delivery from the catchment. Concurrently, the forest expansion attenuates runoff (e.g., due to retention increase), while urbanization increases it (e.g., due to the increase of impermeable areas) (Tellman et al. 2015). However, given the extent of the predicted changes (decrease of areas used for agriculture by $16 \%$ ), the general outcome of the adopted land use scenario (LU) will result in a decrease of the sediment loads by approximately $0.16 \mathrm{Gg} \mathrm{y}^{-1}$ on average.

As presented above, changes of individual climate and land use parameters can result in opposing sediment load trends. Therefore, superimposed precipitation, temperature, and land use predictions are taken into consideration. The combined near future (2021-2050) predictions for the upper Raba River catchment (COMB1) exhibited a decrease of sediment load introduced into the reservoir (by approx. $0.13 \mathrm{Gg} \mathrm{y}^{-1}$ ). This result stems from the predicted land use changes mitigating soil erosion, and therefore, decreasing sediment delivery (Routschek et al. 2014). The far future scenario (2071-2100, COMB2) will possibly bring an increase of sediment delivery by $0.29 \mathrm{Gg} \mathrm{y}^{-1}$ on average. This increase can be attributed to a high percentage of precipitation increase predicted in the winter and spring months for this time horizon.

\section{Conclusions}

For the first time, a detailed modeling study of the impact of changes in climate and land use on sediment loads has been undertaken for a Carpathian catchment. The total loads estimated for the profile representing sediment delivery to the dam reservoir exhibited seasonal/annual variability related to the occurrence of local meteorological phenomena. These predictions of sediment accumulation rate and remaining reservoir capacity are particularly important for reservoir management in the context of sedimentation mitigation planning. The near (2021-2050) and far (2071-2100) future climate change predictions revealed a strong direct correlation of the sediment loads with precipitation increase. However, the aforementioned temperature impact requires particular attention, and further studies on this relationship with sediment loads must be carried out. Since the temperature change by $1-2{ }^{\circ} \mathrm{C}$ resulted in sediment loads decrease by about $5 \%$, a temperature change above $2{ }^{\circ} \mathrm{C}$ caused a decrease in the range of $16 \%$.

In the combined future scenarios, land use exerted the highest impact on sediment loads, which indicates that proper mitigation measures for erosion must be planned for this catchment. However, the question is whether it can be assumed that land use changes, especially enlargement of forest cover, can effectively stop the negative effects of climate changes in mountainous areas affected by water erosion. Regarding this issue, an interesting observation has been made in conjunction with the combined scenarios. For the COMB1 scenario, sediment loads changed by $2 \%$ which indicates that the effects of precipitation, temperature, and land use change balance each other, which is a key conclusion for reservoir management. This indicates that reservoirs located in a mountainous region will be refractory to some extent in the near future to the effects of climate change in the context of sediment load. In the long-term predictions (COMB2), a large increase of sediment load caused by rainfall increase will no longer be offset by a sediment load decrease resulting from the temperature and land use changes. Therefore, anti-erosion actions should be planned for in the future and their cost implemented in the perspective management plans. In a mountainous catchment, afforestation is considered as one of the most effective techniques preventing erosion (Buendia et al. 2016; Kim et al. 2017). Currently, a policy promoting afforestation is pursued both in Poland and throughout the EU. This is especially beneficial for farmers with poorer land quality in regions with severe climatic conditions, such as these in the Raba River catchment. In such cases, farmers who decide to pursue afforestation of their land can benefit from special subsidies. If these activities are continued, it can be expected that the forecasted growth of the forest area forms the LU scenario and will remain realistic. However, it is also important to remember that forest age plays an important factor in protection of soils from erosion. Soil in agricultural areas freshly transformed into forest has higher susceptibility to erosion compared to old forest areas (Yesilonis et al. 2016). It is also important to remember that not only the magnitude of sediment load is important for dam reservoirs but also the analysis of individual sediment size fractions that flow into the reservoir. It is mainly smaller fractions (i.e., clay and silt) that transport the largest amount of pollution such as heavy metals or biogenic compounds. It is these fractions that dominate the 
upper Raba River catchment, constantly posing a threat to the quality of water in the reservoir, and possibly to the people that use this water source for drinking purposes.

Open Access This article is licensed under a Creative Commons Attribution 4.0 International License, which permits use, sharing, adaptation, distribution and reproduction in any medium or format, as long as you give appropriate credit to the original author(s) and the source, provide a link to the Creative Commons licence, and indicate if changes were made. The images or other third party material in this article are included in the article's Creative Commons licence, unless indicated otherwise in a credit line to the material. If material is not included in the article's Creative Commons licence and your intended use is not permitted by statutory regulation or exceeds the permitted use, you will need to obtain permission directly from the copyright holder. To view a copy of this licence, visit http://creativecommons.org/licenses/by/4.0/.

\section{References}

Abbaspour KC, Rouholahnejad E, Vaghefi S, Srinivasan R, Yang H, Kløve B (2015) A continental-scale hydrology and water quality model for Europe: calibration and uncertainty of a high-resolution large-scale SWAT model. J Hydrol 524:733-752. https://doi.org/10. 1016/j.jhydrol.2015.03.027

Ahilan S, Guan M, Sleigh A, Wright N, Chang H (2018) The influence of floodplain restoration on flow and sediment dynamics in an urban river. J Flood Risk Manag 11:S986-S1001. https://doi.org/10.1111/ jfr3.12251

Alighalehbabakhani F, Miller CJ, Baskaran M, Selegean JP, Barkach JH, Dahl T, Abkenar SMS (2017) Forecasting the remaining reservoir capacity in the Laurentian Great Lakes watershed. J Hydrol 555: 926-937. https://doi.org/10.1016/j.jhydrol.2017.10.052

Apitz SE (2012) Conceptualizing the role of sediment in sustaining ecosystem services: sediment-ecosystem regional assessment (SEcoRA). Sci Total Environ 415:9-30. https://doi.org/10.1016/j. scitotenv.2011.05.060

Arnold JG, Moriasi DN, Gassman PW, Abbaspour KC, White MJ, Srinivasan R, Kannan N (2012) SWAT: model use, calibration, and validation. T ASABE 55(4):1491-1508. https://doi.org/10. $13031 / 2013.42256$

Ayaseh A, Salmasi F, Dalir AH, Arvanaghi H (2019) A performance comparison of CCHE2D model with empirical methods to study sediment and erosion in gravel-bed rivers. Int J Sci Environ Technol 16(12):7933-7942. https://doi.org/10.1007/ s13762-019-02229-2

Barrera Crespo PD, Mosselman E, Giardino A, Becker A, Ottevanger W, Nabi M, Arias-Hidalgo M (2019) Sediment budget analysis of the Guayas River using a process-based model. Hydrol Earth Syst Sci 23(6):2763-2778. https://doi.org/10.5194/hess-23-2763-2019

Bryndal T, Franczak P, Kroczak R, Cabaj W, Kołodziej A (2017) The impact of extreme rainfall and flash floods on the flood risk management process and geomorphological changes in small Carpathian catchments: a case study of the Kasiniczanka river (Outer Carpathians, Poland). Nat Hazards 88(1):95-120. https://doi.org/ 10.1007/s11069-017-2858-7

Bucała-Hrabia A (2017a) From communism to a free-market economy: a reflection of socio-economic changes in land use structure in the vicinity of the city (Beskid Sacecki, Western Polish Carpathians). Geogr Pol 90:65-79. https://doi.org/10.7163/GPol.0079
Bucała-Hrabia A (2017b) Long-term impact of socio-economic changes on agricultural land use in the Polish Carpathians. Land Use Policy 64:391-404. https://doi.org/10.1016/j.landusepol.2017.03.013

Buendia C, Bussi G, Tuset J, Vericat D, Sabater S, Palau A, Batalla RJ (2016) Effects of afforestation on runoff and sediment load in an upland Mediterranean catchment. Sci Total Environ 540:144-157. https://doi.org/10.1016/j.scitotenv.2015.07.005

Bussi G, Dadson SJ, Prudhomme C, Whitehead PG (2016) Modelling the future impacts of climate and land-use change on suspended sediment transport in the River Thames (UK). J Hydrol 542:357-372. https://doi.org/10.1016/j.jhydrol.2016.09.010

Bussi G, Janes V, Whitehead PG, Dadson SJ, Holman IP (2017) Dynamic response of land use and river nutrient concentration to long-term climatic changes. Sci Total Environ 590-591:818-831. https://doi. org/10.1016/j.scitotenv.2017.03.069

Cebulska M, Twardosz R (2014) Anomalously wet seasons and years in the polish Carpathian mountains and in their foreland (1881-2010). Przeglad Geofizyczny 3-4:111-126 (in Polish)

Climateimpact (2019) Geoportal on climate change and its impacts in Poland. http://climateimpact.sggw.pl/map/proj/. Accessed 4 April 2019

Da Silva RM, Dantas JC, Beltrão JDA, Santos CA (2018) Hydrological simulation in a tropical humid basin in the Cerrado biome using the SWAT model. Hydrol Res 49(3):908-923. https://doi.org/10.2166/ nh.2018.222

Darby SE, Dunn FE, Nicholls RJ, Rahman M, Riddy L (2015) A first look at the influence of anthropogenic climate change on the future delivery of fluvial sediment to the Ganges-Brahmaputra-Meghna delta. Environ Sci Process Impacts 17(9):1587-1600. https://doi. org/10.1039/C5EM00252D

Drzewiecki W, Mularz S (2008) Simulation of water soil erosion effects on sediment delivery to Dobczyce reservoir. ISPRS J P\&RS 37:B8

Fox GA, Sheshukov A, Cruse R, Kolar RL, Guertault L, Gesch KR, Dutnell RC (2016) Reservoir sedimentation and upstream sediment sources: perspectives and future research needs on streambank and gully erosion. Environ Manag 57(5):945-955. https://doi.org/10. 1007/s00267-016-0671-9

Fukunaga DC, Cecílio RA, Zanetti SS, Oliveira LT, Caiado MAC (2015) Application of the SWAT hydrologic model to a tropical watershed at Brazil. Catena 125:206-213. https://doi.org/10.1016/j.catena. 2014.10.032

Giardino A, Schrijvershof R, Nederhoff CM, De Vroeg H, Brière C, Tonnon PK, Caires S, Walstra DJ, Sosa J, Van Verseveld W, Schellekens J (2018) A quantitative assessment of human interventions and climate change on the West African sediment budget. Ocean Coast Manage 156:249-265. https://doi.org/10.1016/j. ocecoaman.2017.11.008

Grecequet M, DeWaard J, Hellmann JJ, Abel GJ (2017) Climate vulnerability and human migration in global perspective. Sustainability 9(5):720. https://doi.org/10.3390/su9050720

Hattermann FF, Krysanova V, Gosling SN, Dankers R, Daggupati P, Donnelly C, Flörke M, Huang S, Motovilov Y, Buda S, Yang T (2017) Cross-scale intercomparison of climate change impacts simulated by regional and global hydrological models in eleven large river basins. Clim Chang 141(3):561-576. https://doi.org/10.1007/ s10584-016-1829-4

Jentsch A, Beierkuhnlein C (2008) Research frontiers in climate change: effects of extreme meteorological events on ecosystems. Compt Rendus Geosci 340(9-10):621-628. https://doi.org/10.1016/j.crte. 2008.07.002

Jokiel P, Tomalski P (2017) Seasonality of outflow in selected Carpathian catchments. Przegląd Geograficzny 89(1):29-44 (in Polish)

Kim G, Lim CH, Kim S, Lee J, Son Y, Lee WK (2017) Effect of nationalscale afforestation on forest water supply and soil loss in South Korea, 1971-2010. Sustainability 9(6):1017. https://doi.org/10. $3390 / \mathrm{su} 9061017$ 
Kodoatie RJ (2000) Sediment transport relations in alluvial channels. Unpublished PhD Thesis. Colorado State University, Colorado, USA

Krishnan N, Raj C, Chaubey I, Sudheer KP (2018) Parameter estimation of SWAT and quantification of consequent confidence bands of model simulations. Environ Earth Sci 77(12):470-416. https://doi. org/10.1007/s12665-018-7619-8

Kumar N, Singh SK, Srivastava PK, Narsimlu B (2017) SWAT model calibration and uncertainty analysis for streamflow prediction of the tons River Basin, India, using sequential uncertainty fitting (SUFI-2) algorithm. Model Earth Syst Environ 3(1):30-13. https://doi.org/10. 1007/s40808-017-0306-z

Lee S, Sadeghi AM, Hively WD, Lang MW, Sharifi A (2018) Comparative analyses of hydrological responses of two adjacent watersheds to climate variability and change using the SWAT model. Hydrol Earth Syst Sci 22(1):689-708. https://doi.org/10.5194/hess22-689-2018

Libera DA, Sankarasubramanian A (2018) Multivariate bias corrections of mechanistic water quality model predictions. J Hydrol 564:529 541. https://doi.org/10.1016/j.jhydrol.2018.07.043

Liu Y, Yang W, Yu Z, Lung I, Gharabaghi B (2015) Estimating sediment yield from upland and channel erosion at a watershed scale using SWAT. Water Res Manage 29(5):1399-1412. https://doi.org/10. 1007/s11269-014-0729-5

Lu XX, Ran LS, Liu S, Jiang T, Zhang SR, Wang JJ (2013) Sediment loads response to climate change: a preliminary study of eight large Chinese rivers. Intern J Sed Res 28(1):1-14. https://doi.org/10.1016/ S1001-6279(13)60013-X

Mannschatz T, Wolf T, Hülsmann S (2016) Nexus tools platform: webbased comparison of modelling tools for analysis of water-soilwaste nexus. Environ Model Softw 76:137-153. https://doi.org/10. 1016/j.envsoft.2015.10.031

Marhaento H, Booij MJ, Rientjes THM, Hoekstra AY (2017) Attribution of changes in the water balance of a tropical catchment to land use change using the SWAT model. Hydrol Proc 31(11):2029-2040. https://doi.org/10.1002/hyp.11167

Mazurkiewicz-Boron G (2016) Catchment conditions, chemistry, and water trophies. In: Sadag T, Bandula T, Materek E, MazurkiewiczBoron G, Slonki R (eds) The Dobczyce reservoir. Attyka, Krakow, pp 147-153 (in Polish)

Mezghani A, Dobler A, Haugen JE, Benestad RE, Parding KM, Piniewski M, Kardel I, Kundzewicz ZW (2017) CHASE-PL climate projection dataset over Poland-bias adjustment of EURO-CORDEX simulations. Earth Syst Sci Data 9:905-925. https://doi.org/10.5194/ essd-2017-51

Nguyen HH, Recknagel F, Meyer W, Frizenschaf J, Ying H, Gibbs MS (2019) Comparison of the alternative models SOURCE and SWAT for predicting catchment streamflow, sediment and nutrient loads under the effect of land use changes. Sci Total Environ 662:254 265. https://doi.org/10.1016/j.scitotenv.2019.01.286

Operacz A (2017) The term "effective hydropower potential" based on sustainable development-an initial case study of the Raba river in Poland. Renew Sust Energ Rev 75:1453-1463. https://doi.org/10. 1016/j.rser.2016.11.141

Ostojski MS (2012) Modeling processes of biogenic compounds discharge to the Baltic Sea: on the example of total nitrogen and phosphorus. Wydawnictwo Naukowe PWN, Warszawa (in Polish)

Patil SD, Stieglitz M (2015) Comparing spatial and temporal transferability of hydrological model parameters. J Hydrol 525:409-417. https://doi.org/10.1016/j.jhydrol.2015.04.003

Price B, Kaim D, Szwagrzyk M, Ostapowicz K, Kolecka N, Schmatz DR, Wypych A, Kozak J (2017) Legacies, socio-economic and biophysical processes and drivers: the case of future forest cover expansion in the Polish Carpathians and Swiss Alps. Reg Environ Chang 17(8):2279-2291. https://doi.org/10.1007/s10113-016-1079z
Ricci GF, De Girolamo AM, Abdelwahab OM, Gentile F (2018) Identifying sediment source areas in a Mediterranean watershed using the SWAT model. Land Degrad Dev 29(4):1233-1248. https://doi.org/10.1002/ldr.2889

Routschek A, Schmidt J, Kreienkamp F (2014) Impact of climate change on soil erosion - a high-resolution projection on catchment scale until 2100 in Saxony/Germany. Catena 121:99-109. https://doi. org/10.1016/j.catena.2014.04.019

Shrestha NK, Wang J (2018) Predicting sediment yield and transport dynamics of a cold climate region watershed in changing climate. Sci Total Environ 625:1030-1045. https://doi.org/10.1016/j. scitotenv.2017.12.347

Simonneaux V, Cheggour A, Deschamps C, Mouillot F, Cerdan O, Le Bissonnais Y (2015) Land use and climate change effects on soil erosion in a semi-arid mountainous watershed (High Atlas, Morocco). J Arid Environ 122:64-75. https://doi.org/10.1016/j.jaridenv.2015.06.002

Stryker J, Wemple B, Bomblies A (2018) Modeling the impacts of changing climatic extremes on streamflow and sediment yield in a northeastern US watershed. J Hydrol Reg Stud 17:83-94. https://doi.org/ 10.1016/j.ejrh.2018.04.003

Szalińska E, Wilk P (2018) Sediment quantity management in Polish catchment-river-sea systems - should we care? Econ Environ 66(3):25-37

Szalińska E, Orlińska-Woźniak P, Wilk P (2018) Nitrate vulnerable zones revision in Poland - assessment of environmental impact and land use conflicts. Sustainability 10(9):3297. https://doi.org/10.3390/ su10093297

Szwagrzyk M, Kaim D, Price B, Wypych A, Grabska E, Kozak J (2018) Impact of forecasted land use changes on flood risk in the Polish Carpathians. Nat Hazards 94:227-240. https://doi.org/10.1007/ s11069-018-3384-y

Tasser E, Leitinger G, Tappeiner U (2017) Climate change versus landuse change - what affects the mountain landscapes more? Land Use Policy 60:60-72. https://doi.org/10.1016/j.landusepol.2016.10.019

Tellman B, Saiers JE, Cruz OAR (2015) Quantifying the impacts of land use change on flooding in data poor watersheds in El Salvador with community-based model calibration. Reg Environ Chang 16(4): 1183-1196. https://doi.org/10.1007/s10113-015-0841-y

Verburg PH, Eickhout B, van Meij H (2008) A multi-scale, multi-model approach for analyzing the future dynamics of European land use. Ann Reg Sci 42:57-77. https://doi.org/10.1007/s00168-007-0136-4

Walling DE (2017) Measuring sediment yield from river basins. In: Lal L (ed) Soil erosion research methods, 2nd edn. Routledge, pp 39-82

Wang S, Fu B, Piao S, Lü Y, Ciais P, Feng X, Wang Y (2016) Reduced sediment transport in the Yellow River due to anthropogenic changes. Nat Geosci 9(1):38. https://doi.org/10.1038/NGEO2602

Wilk P, Gębala J, Orlińska-Woźniak P, Ostojski M (2017) Flattening phenomenon in seasonal variability analysis of total nitrogen loads in river waters. Tech Trans 11(114):137-159. https://doi.org/10. 4467/2353737XCT.17.195.7425

Wilk P, Orlińska-Woźniak P, Gębala J (2018a) The river absorption capacity determination as a tool to evaluate state of surface water. Hydrol Earth Syst Sci 22(2):1033. https://doi.org/10.5194/hess-221033-2018

Wilk P, Orlińska-Woźniak P, Gębala J (2018b) Mathematical description of a river absorption capacity on the example of the middle Warta catchment. Environ Protect Eng 44(4):99-115. https://doi.org/10. 5277/epe180407

Xing L, Zuo J, Liu F, Zhang X, Cao Q (2018) Simulation of agricultural non-point source pollution in Xichuan by using SWAT model. IOP Conf Ser Earth Environ Sci 113(1):012167. https://doi.org/10.1088/ $1755-1315 / 113 / 1 / 012167$

Yang SL, Xu KH, Milliman JD, Yang HF, Wu CS (2015) Decline of Yangtze River water and sediment discharge: impact from natural and anthropogenic changes. Sci Rep 5:12581 
Yesilonis I, Szlavecz K, Pouyat R, Whigham D, Xia L (2016) Historical land use and stand age effects on forest soil properties in the midAtlantic US. Forest Ecol Manag 370:83-92. https://doi.org/10.1016/ j.foreco.2016.03.046

Zhou Y, Xu Y, Xiao W, Wang J, Huang Y, Yang H (2017) Climate change impacts on flow and suspended sediment yield in headwaters of high-latitude regions - a case study in China's far northeast. Water 9(12):966. https://doi.org/10.3390/w9120966

Publisher's note Springer Nature remains neutral with regard to jurisdictional claims in published maps and institutional affiliations. 